\title{
Production and verification of the first Atlantic salmon (Salmo salar L.) clonal lines
}

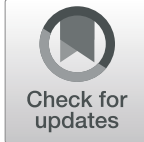

\author{
Tom Johnny Hansen ${ }^{1 *}$ (D), David Penman², Kevin Alan Glover ${ }^{3,4}$, Thomas William Kenneth Fraser ${ }^{1}$, Tone Vågseth ${ }^{1}$, \\ Anders Thorsen ${ }^{3}$, Anne Grete Eide Sørvik ${ }^{3}$ and Per Gunnar Fjelldal ${ }^{1}$
}

\begin{abstract}
Background: In several fish species homozygous and heterozygous clonal lines have been produced using gynogenetic and androgenetic techniques. These lines are standardized and can be reproduced over generations. In rainbow trout such lines have existed for decades and has become important research tools in genome studies as well as in studies of commercially important traits. The Atlantic salmon is one of the best studied fish species globally, but all experiments are done on fish of wild or domesticated origin and access to standardized immortal fish lines would be of great benefit. Here, we describe the protocols developed to produce mitotic gynogenes, and from these the first clonal lines in Atlantic salmon.

Results: Atlantic salmon eggs fertilized with UV irradiated sperm combined with a pressure shock applied at 47004800 minC at $8{ }^{\circ} \mathrm{C}$ gave all homozygous (doubled haploid) gynogenetic progeny with high survival. From the six first maturing females, five all homozygous clonal lines were produced by meiotic gynogenesis and were verified as clonal and identical to their mother with microsatellite markers.

Conclusions: We have now produced the first documented cloned Atlantic salmon lines. This work demonstrates the potential for production of further Atlantic salmon clonal lines, potentially with distinct characteristics. Such lines will provide an important resource for further elucidation of phenotypic and genetic traits in this globally important species.
\end{abstract}

Keywords: Meiotic and mitotic gynogenesis, Doubled haploids, Clones, Microsatellite, Fish

\section{Background}

In fish, progeny after parthenogeneic development can be viable [1] and after the pioneering work on zebrafish, Brachydanio rerio [2], protocols for controlled production of meiotic gynogenetics and double haploid mitotic gynogenetics and androgenetics have been developed (reviewed by $[1,3]$ ). In several species of fish (e.g. zebrafish [2]; Nile tilapia, Oreochromis niloticus L. [4]; Common carp, Cyprinus carpio [5]; amago salmon, Oncorhynchus rodurus [6]; rainbow trout, Oncorhynchus mykiss [7, 8], homozygous or heterozygous clonal lines have also been produced from

\footnotetext{
* Correspondence: tomh@hi.no

${ }^{1}$ Institute of Marine Research, 5984 Matredal, Norway

Full list of author information is available at the end of the article
}

the double haploid mitotic gynogenetics and/or androgenetics. These doubled haploids and/or clones have multiple applications as research animals, as they are standardized and can be reproduced over generations (reviewed by [3, 9]).

Among the salmonids, both rainbow trout (Oncorhynchus mykiss) and Atlantic salmon (Salmo salar) have become important aquaculture production animals. In rainbow trout, doubled haploid and clonal lines were established early (see [7, 8]) and have been utilized in the production of linkage maps [10, 11], detection of QTLs for meristic traits [12] and investigations of developmental rate [13]. They have also proved valuable in detailed analysis of commercially important traits such as disease resistance and

(c) The Author(s). 2020 Open Access This article is licensed under a Creative Commons Attribution 4.0 International License, which permits use, sharing, adaptation, distribution and reproduction in any medium or format, as long as you give appropriate credit to the original author(s) and the source, provide a link to the Creative Commons licence, and indicate if changes were made. The images or other third party material in this article are included in the article's Creative Commons licence, unless indicated otherwise in a credit line to the material. If material is not included in the article's Creative Commons licence and your intended use is not permitted by statutory regulation or exceeds the permitted use, you will need to obtain permission directly from the copyright holder. To view a copy of this licence, visit http://creativecommons.org/licenses/by/4.0/ The Creative Commons Public Domain Dedication waiver (http://creativecommons.org/publicdomain/zero/1.0/) applies to the data made available in this article, unless otherwise stated in a credit line to the data. 
utilization of animal contra vegetable dietary sources. Different rainbow trout clones show a wide range of susceptibility to viruses like the infectious salmon anaemia virus [14], the rhabdoviruses viral haemorrhagic septicaemia virus (VHSV) and infectious haematopoietic necrosis virus (IHNV) [15], and have been used to identify a major QTL for resistance to VHSV [16]. They also show a wide range of susceptibility to the bacteria Flavobacterium psychrophilum and have been used to gain insights into the genetic basis of the rainbow trout's natural resistance to this bacteria [17]. In a pioneering study on utilization of marine/vegetable dietary sources [18], clonal rainbow trout lines were used to describe a genotype $\mathrm{x}$ protein source interaction in feed intake and feed efficiency and final weight following two feeding periods. A follow-up study describe how an early short-term exposure of fry improved the acceptance and utilisation of the same diet at a later life stage [19].

Atlantic salmon is also one of the most domesticated fishes [20, 21], and is also one of the best studied globally with extensive genomic resources [22]. A wide variety of experiments have been conducted on this species, using fish of wild and domesticated origin. However, for a long time it has been noted that access to standardized and genetically defined fish would greatly benefit the scientific community [23]. Production of meiotic gynogenetics using ${ }^{60} \mathrm{Co}$ irradiated sperm and cold shock was unsuccessful [24], but the use of ${ }^{60} \mathrm{Co}$ irradiated Atlantic salmon sperm [25] and UV light (UV) irradiated rainbow trout sperm [26], combined with heat shock, produced meiotic gynogenetics. Later, mitotic gynogenetics were produced [27] using UV irradiated milt and pressure shocks, but the progeny was terminated after 24 months and the production of clonal lines was not attempted.

In the present study we describe the development of a protocol for production of Atlantic salmon mitotic gynogenetic fish, and compare their growth with outbred progeny from the same broodfish and describe their phenotypic development and sexual maturation. We also present data from the production of isogenic lines from the first females that entered sexual maturation and the genotypic and phenotypic evaluation of these lines.

\section{Results}

\section{Optimizing the mitotic gynogenesis protocol}

In the eggs that were fertilized with unirradiated milt to determine the first cleavage interval (FCI), the first signs of cleavage were found after $750 \mathrm{mins}(6000 \mathrm{minC})$ and all eggs were at the 2 cell stage after 790 mins $(6320$ $\operatorname{minC}$ ). Fifty \% cleavage was between 6160 and 6240 $\operatorname{minC}$ and was set to $6200 \mathrm{minC}$.

In the two experiments attempting to optimize the mitotic gynogenesis protocol (Exp2011 and Exp2012), surviving progeny were found in all pressure treatments between 4400 and $5100 \mathrm{minC}$, with the highest survival at $4700(\operatorname{Exp} 2012)$ and $4800 \mathrm{minC}(\operatorname{Exp} 2011)$ at $8^{\circ} \mathrm{C}$, with only minor effects of UV protocol (Table 1). Mean survival until first feeding in the $4800 \mathrm{minC}$ groups in Exp2011 (mean of 6 and 8 mins UV protocols) was $20.2 \%$ (or $23.3 \%$ of the survival in the controls). In Exp2012 the highest survival until first feeding was found at $4700 \mathrm{minC}$ with $10.2 \%$ (12.3\% of controls), but acceptable survival was also found at $4800 \mathrm{minC}$ with $6.5 \%$ (7.8\% of controls). However, early mortalities (mainly during first feeding) were considerable. In Exp2011, survival until tagging and DNA sampling (7 August 2012; 107 days after first feeding; mean weight $17.8 \mathrm{~g}$ ) was $14.3 \%$ (16.7\% of controls; mean of 2 UV protocols), and in Exp2012, survival until tagging and DNA sampling (18 September 2013; 180 days after first feeding; mean weight $41.2 \mathrm{~g}$ ) was $7.9 \%$ for $4700 \mathrm{minC}(9.6 \%$ of controls) and $5.7 \%$ for $4800 \mathrm{minC}$ ( $6.9 \%$ of controls). After tagging mortality was very low and the reduction in numbers of fish (Additional file 1: Table S1) are mainly due to sampling and removal of stunted and deformed fish.

The female egg donor in Exp2011 was heterozygous for 15 of the 18 analyzed microsatellites (Additional file 2: Table S2) and the sperm donor had at least one allele that was not shared with the female for 16 of the 18 analyzed microsatellites. For eight of the microsatellites, the male and female did not share alleles. Microsatellite analysis from the August 2012 sampling (Additional file 2: Table S2) showed that the control group of offspring was heterozygous with markers from both male and female. Of the 319 fish from the treatment groups, 317 were homozygous for all markers and carried only alleles from the egg donor. Two individuals were heterozygous

Table 1 Survival from fertilisation to first feeding/tagging (dates are given in the text) of groups of salmon eggs fertilised with UV light irradiated and unirradiated control sperm

\begin{tabular}{|c|c|c|c|c|c|c|c|c|c|c|}
\hline \multirow[t]{2}{*}{ Date } & \multirow{2}{*}{$\begin{array}{l}\text { UV } \\
\text { (mins) }\end{array}$} & \multirow[b]{2}{*}{$<4400$} & \multirow[b]{2}{*}{4400} & \multicolumn{7}{|c|}{ Pressure induction time (minutedegrees postfertilisation) } \\
\hline & & & & 4600 & 4700 & 4800 & 4900 & 5000 & 5100 & Contr \\
\hline \multirow[t]{2}{*}{14 Dec 2011} & 6 & $0 / 0$ & $0.1 / 0.0$ & $1.7 / 1.2$ & & $19.3 / 13.5$ & & & & $86.6 / 85.8$ \\
\hline & 8 & & $0.3 / 0.2$ & $2.8 / 1.7$ & & $21.0 / 15.1$ & & & & $86.6 / 85.8$ \\
\hline 12 Dec 2012 & 6 & & & & $10.2 / 7.9$ & $6.5 / 5.7$ & $1.1 / 1.1$ & $1.0 / 0.9$ & $2.11 / 1.55$ & $83.1 / 82.1$ \\
\hline
\end{tabular}


and also displayed alleles from the sperm donor. These two individuals, one of each sex, were removed from the experimental population. The control group had 23 females and 22 males.

The length, weight, condition factor, fish numbers and the sexual maturation for the fish from the controls and the different treatment protocols in Exp 2011 are presented in Additional file 1: Table S1. No significant differences in mean weight were found at any time either between the control group and the treatment groups (two first samples) or between the treatment groups at any time. The treatment groups had a much higher variation than the controls (cv 2-3 times higher; data not shown), with a high frequency of small fish (e.g. 20.3\% of the treatment groups were smaller than the smallest fish in the control group in November 2012). However, some individuals also grew well with 5 individuals from the treatment groups being heavier than any of the controls (Fig. 1b). In November 2012 when the deformed fish and most of the controls were euthanized, the treatment groups were significantly shorter and had a higher condition factor than the controls (Fig. 1, Additional file 1: Table S1). The different treatment groups also had higher variation than the controls for all measured parameters (Additional file 1: Table S1; Fig. 1). After the deformed fish and most of the controls were euthanized (Fig. 1, Additional file 1: Table S1) no significant differences were found between the remaining groups at any time. The radiographs from June 2013 revealed vertebral deformities in 4 of the 30 individuals from the treatment groups with no deformities being found in the control fish. The deformities affected 2 to 4 vertebrae and were compressions, or combinations of compressions and fusions.

In 2014, six mature fish were found in the $4800 / 8$ group and individuals matured also in 2015 and 2016, and a few fish were still immature when the study was terminated in 2016.

\section{Production of clonal lines}

The six females that matured in 2014 (Table 2) gave between 4886 and 6706 eggs corresponding to between 1517 and 2261 eggs per $\mathrm{kg}$ bodyweight. Five of these lines gave surviving progeny and after 60 days of feeding survival varied between 3.9 and $28.3 \%$. The two most abundant lines had 1795 (line 3) and 1764 (line 6) surviving progeny after 60 days of feeding. On 30 November (235 days of feeding), the mean weight of the lines varied between $49 \mathrm{~g}$ (line 5) and $125 \mathrm{~g}$ (line 6) and all individuals in all lines were females. Two of the lines (lines 5 and 6) had a very high incidence of vertebral deformities with 'short tail' being the most common $(34.2 \%$ in line 5 and $29.7 \%$ in line 6 ). The high incidence of deformities was also reflected in the high $\mathrm{K}$ in line 5 and 6 . Line 5

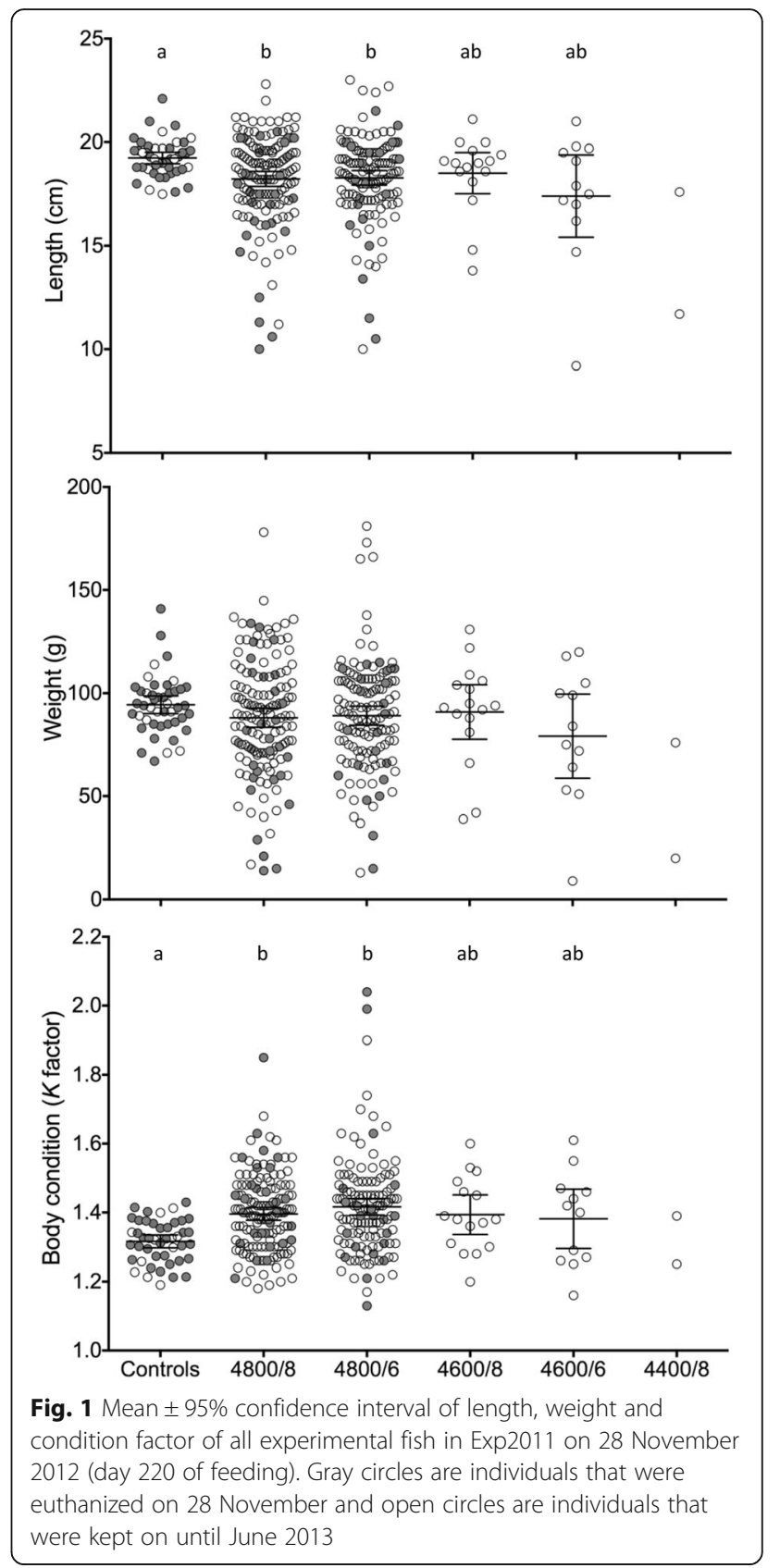

also had a high incidence of curvatures (36.8\%) and $76.3 \%$ missed the pelvic fin. Line 3 had no deformities, good growth and the highest survival. Microsatellite analysis of the fish sampled on 16 November 2015 confirmed that all progeny were homozygous and identical to their mothers. This is with the exception of individuals 5 and 6 in cloned line 2 (Additional file 2: Table S2). For these two fish, one of the eighteen markers presented a single homozygoes allele that was $8 \mathrm{bp}$ shorter than the mother's single allele for that marker. The underlying cause(s) of this anomaly are not known. However, microsatellites are known to mutate through a 
Table 2 Length, weight and egg production of the six mitotic gynogenetic clonal line progenitors maturing in 2014 and the survival, growth and phenotypic description of their offspring. *Female 5 was only partly ovulated

\begin{tabular}{|c|c|c|c|c|c|c|}
\hline & \multicolumn{6}{|l|}{ Line $\mathrm{nr}$} \\
\hline & 1 & 2 & 3 & 4 & 5 & 6 \\
\hline Length $(\mathrm{cm})$ of female & 63.9 & 65.8 & 60.7 & 66.7 & 61.3 & 68.0 \\
\hline Weight (g) of stripped female & 2790 & 2509 & 2803 & 3460 & 3220 & 4175 \\
\hline Eggs (N) & 5469 & 4867 & 6340 & 6204 & $4886^{*}$ & 6706 \\
\hline Survival eyed stage (\%) & 73.6 & 39.5 & 72.8 & 0 & 44.0 & 97.9 \\
\hline Survival to first feeding (\%) & 36.2 & 24.6 & 43.5 & 0 & 8.2 & 65.7 \\
\hline Survival after 60 days feeding (\%) & 15.8 & 14.0 & 28.3 & 0 & 3.9 & 26.3 \\
\hline Survival after 60 days feeding (N) & 864 & 680 & 1795 & 0 & 189 & 1764 \\
\hline \multicolumn{7}{|l|}{ Sampling 30 November 2015} \\
\hline N sampled & 28 & 24 & 30 & & 38 & 37 \\
\hline Weight (g) (SD) & $54(14)$ & $125(30)$ & $90(25)$ & & $49(28)$ & $79(25)$ \\
\hline Condition factor K (SD) & $1.18(0.08)$ & $1.24(0.10)$ & $1.24(0.08)$ & & $1.39(0.27)$ & $1.47(0.36)$ \\
\hline Sex F/M & $28 / 0$ & $24 / 0$ & $30 / 0$ & & $38 / 0$ & $37 / 0$ \\
\hline Missing pelvic & 4 & & & & 29 & 3 \\
\hline Short trunk & 1 & 1 & & & 2 & 3 \\
\hline Short tail & & 1 & & & 13 & 11 \\
\hline Upper jaw & & & & & 1 & \\
\hline Lower jaw & & & 1 & & & \\
\hline Scoliosis & & & & & 6 & \\
\hline Kyphosis & & & & & 2 & \\
\hline Lordosis & & & & & 6 & 3 \\
\hline Opercula & & & & & & 1 \\
\hline
\end{tabular}

slippage of one or two repeats in the motiv, in this case by $4-8 \mathrm{bp}$, and could explain the observation $[28,29]$.

\section{Discussion}

This study describes the methods and production of the first cloned Atlantic salmon lines. In two experiments fertilization with UV irradiated sperm combined with a pressure shock applied at $4700-4800 \mathrm{minC}$ at $8{ }^{\circ} \mathrm{C}$ gave all homozygous (doubled haploid) gynogenetic Atlantic salmon, with survival rates ranging from 9.6 to $16.7 \%$ after 107 to 180 days of feeding. Based on the absence of paternal inheritance found in the microsatellite loci and the female sex of the progeny (Additional file 1), we conclude that both UV protocols (6 and 8 mins) used in Exp2011 gave a complete inactivation of the sperm DNA. Also, the homozygosity for all investigated loci in the progeny show that they are produced by first cleavage block gynogenesis and not spontaneous polar body retention. A blockage of the second meiotic division would leave some level of heterozygosity [30], as the female progenitor had a high level of allelic heterozygosity (15 out of 18 of the investigated loci).

The timing of the pressure shock in Exp2011 (3800 to 4800) were chosen after [27] who produced mitotic gynogenetics when activating salmon eggs with UV irradiated sperm and using pressure shock at 400 to 470 mins after fertilization at $10{ }^{\circ} \mathrm{C}$, finding an optimized timing at $440 \mathrm{mins}(4400 \mathrm{minC})$. In our two experiments we found an optimized induction time around 4700 to $4800 \mathrm{minC}$, corresponding to between 75.8 and $77.4 \%$ of the FCI (using the 6200 FCI found in Exp2011 which agrees well with the FCI of 6240 described earlier [31].

Optimal timing of a temperature or pressure shock has earlier been shown to coincide with the metaphase $[2,5,32,33]$ and/or prometaphase [34] of the mitosis, preventing the partitioning of the duplicated chromosomes into two cells. The result is a cell with two identical sets of chromosomes [2]: doubled haploids when using UV irradiated sperm, or tetraploids when using intact sperm. Our optimized timing agrees well with studies done on several other species, reported to be $65 \pm 5 \%$ of the FCI in rainbow trout [35], 70-72.5\% in brook trout [36], 70-75\% in common carp [5], but differs from 45.8-57.2\% in pressure-shocked Nile tilapia [37, 38]. However, variation between studies and species exist as FCI is dependent on temperature [39], increases during the spawning season and with postovulatory ageing of the eggs [35], can vary between populations [39, 40], 
from year to year in the same population [36] and varies between females [34].

The survival until first feeding of doubled haploids was considerably higher in Exp2011 (22-24\% of controls) than in Exp2012 (12.3\% of controls), however, both were in the range of the average of $19 \%$ found in rainbow trout [41] and 14-16\% surviving swim-up fry in brown trout [42]. In studies on other species, survival varies considerably. Twentynine \% normal-appearing embryos were found $24 \mathrm{~h}$ after fertilization in zebrafish [2], compared with 0-6\% survival until hatching in Medaka [43], $3.5-15 \%$ normal fry $96 \mathrm{~h}$ after fertilization in common carp [5], < 1-26\% feeding fry varying between females in loach (Misgurnus anguillicaudatus) [44], 6.9\% of control at yolk sac resorption in Nile tilapia [4] and $12.8 \%$ until hatching in red sea bream [45]. However, these studies do not represent long-time survival as doubled haploid progeny often suffer high mortalities during early life. In [41] the progeny of the six best females of 15 had a mean survival until first feeding of approximately $30 \%$ which was reduced by approximately one third to $20 \%$ during the first 150 days of feeding, comparing well with the mortality of approximately 30\% during the first 107 days of feeding in the present study (Table 1). Still this survival is high compared to other species, with $5.8 \%$ survival until adults in zebrafish [2], 0.2\% in medaka [43], mortalities between 36.1 and $57.3 \%$ between hatching and 28 days post-hatching in common carp [5], mortality of $91.4 \%$ at 90 days in red sea bream [45] and survival of 155 of 323 hatching doubled haploid progeny in Nile tilapia [46]. The survival of doubled haploid progeny from 15 rainbow trout females varied between 0 and $53 \%$, and it was hypothesized that genetic factors could explain part of the variation [41]. Generally, the main factors influencing on the yield/survival of doubled haploids are species-specific gene dosage compensation mechanisms, expression of early embryonic recessive homozygous deleterious mutations, egg quality and the occurrence of spontaneous absorption of the polar body creating heterozygous meiotic diploids [see reviews 3, 9]. In the present study the egg quality was good (high survival of controls) and no heterozygous meiotic diploids were observed, giving support to the hypothesis that genetic factors, i.e. occurrence of recessive deleterious alleles, was the main reason for the reduction in early survival.

In the present study, no significant differences in mean weight were found at any time between the control group and the treatment groups or among the treatment groups. However, our groups are based on one female progenitor. In rainbow trout, the mean weight of groups of mitotic gynogenetics were less than $80 \%$ of that of the diploid controls after 103 days of feeding [41], with the reduction varying between 4.1 and $30.9 \%$ dependent on the female progenitor. Also, the much higher variation than in the controls, the high frequency of small fish, the significantly higher condition factor, and the higher incidence of individuals with curved or shortened vertebral column in the doubled haploids agrees well with earlier studies. Red sea bream mitotic gynogenetics were compared with diploid controls for almost 3 years following hatching and the gynogentics had lower weight from year one on, a higher body depth, a much higher variance in measured parameters, and a higher incidence of short vertebral columns, scoliosis and deformities in the head [45]. In carp mitotic gynogenetics had lower weight and higher variance compared to controls [47] and doubled haploid tilapia had high incidence of deformities and retarded growth [46]. Our radiological examination in June 2013 revealed that 4 out of the 30 radiographed dh individuals had vertebral deformities which can affect the condition factor (see [48]). However, the number of affected fish and the low number of affected vertebrae is too low to explain the observed differences in condition factor between the doubled haploids and controls. The low incidence of deformities and also the fact that some of the doubled haploid individuals are heavier than the controls in November 2012 (Fig. 1b), indicate a potential for production of well-performing doubled haploids with a normal phenotype.

\section{Production of clonal lines}

In this study five all homozygous clonal lines were produced by meiotic gynogenesis of eggs from doubled haploid progenitors and verified as clonal and identical to their mother with microsatellite markers.

Poor reproductive performance of doubled haploid progenitors has been highlighted as a major limitation in the production of isogenic lines $[9,44]$. The relative fecundity (eggs/kg female bodyweight) of doubled haploid rainbow trout was normal and even significantly higher than controls [7], but with observations of sterile and hypofertile fish, and homozygous carp females had severe gonadal defects and less than 10\% could be reproduced [5]. In our study, egg production of the female progenitors was high and well within what is normally seen in outbred Atlantic salmon (e.g. [49, 50]). However, early mortality was high, in accordance with studies on other species; e.g. between 3.3 and $36.9 \%$ of controls in tilapia [51], less than $5 \%$ survival until yolk sac resorption in Nile tilapia [52], between 0 and $70 \%$ survival until hatch in medaka [43], and 29 and $50 \%$ survival until first feeding at first and second spawning in rainbow trout [7].

The treatment protocol that is used, i.e. the UVirradiation protocol of the sperm which can leave fragments of chromosomes [42, 53] and the pressure treatment of the eggs [3] can potentially contribute to the mortality in the clonal lines as well as in the 
production of the dh progenitors. However, both the UV-irradiation protocol and the pressure treatment protocol that was used in the present study are strictly standardized and cannot explain the variation in survival between the lines. Moreover, the pressure treatment protocol is used extensively in production of triploids both for aquaculture production and for research purposes. Different triploid induction protocols have been tested in brown trout [54] and Arctic charr (Salvelinus alpinus) [55], and despite a high variation in the parameters (pressure, timing and duration of pressure) they found a high triploidisation rate, and a survival that is high, and only occasionally significantly different from controls. If the pressure shock itself had some detrimental effect on egg/larval development and survival, one would expect this to be consistent over studies and in the case of our study give the same effect in all lines. Neither should the early mortality in production of homozygous clonal lines be influenced by lethal alleles because they have been eliminated in the first generation [9]. However, each line still represents only one haplotype (extreme inbreeding) and can contain homozygous alleles that are detrimental which again can be mirrored in the variation in phenotype and survival within and between lines as seen in the present material. Also, in our study all the $\mathrm{dh}$ females were stripped for eggs on the same day and the time of ovulation was not recorded. Hence, as post-ovulatory aging is an important determinant for egg quality (e.g. $[56,57]$ this could be an important variable leading to differences in survival. The importance of egg quality has also been demonstrated in rainbow trout where survival until first feeding increased from $29 \%$ in first time spawning doubled haploids to $50 \%$ in their second spawning [7]. Also, both the extreme inbreeding and possibly also a post-ovulatory aging of the eggs are factors that can contribute to the different morphological deviations and deformities that were seen in our clonal lines. The effect of inbreeding on body deformities is well described in studies on both salmon [58] and rainbow trout [59] and in fully homozygous fish the incidence can be considerable [53]. However, in salmon, deformations linked to post-ovulatory aging were mainly found in the head [57] and these were not seen in the present study.

\section{Conclusions}

We have now produced the first documented cloned Atlantic salmon lines, and demonstrated the potential for production of further Atlantic salmon clonal lines, potentially with distinct characteristics. After thorough testing and description, a selection of these lines could make up an important resource of standardized animals in experimental studies and provide an important resource for further elucidation of phenotypic and genetic traits in this globally important species. At the moment we are keeping 11 lines at the institute, and they all originate from Exp2011 and Exp2012 described above. Line 3 which is described in this study has been reproduced in 2018 and 2019, and four lines that originated from Exp2012 were reproduced again in 2019. The lines are now a very important part of our research infrastructure.

\section{Methods}

\section{Sperm irradiation protocol}

The sperm irradiation protocol was developed in 2011 from the protocol for cod sperm [60], using the same equipment, the recommended dilution $(1: 40)$ and the same germicidal UV lamp $(254 \mathrm{~nm}, 15 \mathrm{~W}, 220 \mathrm{~V}, 50 \mathrm{~Hz})$. Milt was diluted with milt fluid (milt from several males were centrifuged until clear and the clear milt fluid was frozen and stored at $-20^{\circ} \mathrm{C}$ and thawed before the experiment). $15 \mathrm{~mL}$ aliquots of the diluted milt was placed in a $9 \mathrm{~cm}$ petridish surrounded by ice and placed on top of a magnetic stirrer and irradiated at $0.48 \mathrm{mWcm}^{-2}$ (VLX-3.W radiometer, Cole Parmer, USA). The sourcefilter to sample distance was maintained at $20 \mathrm{~cm}$ throughout the experiments. Optimal irradiation dose (50\% activity compared to diluted unirradiated sperm (see [60]), was found to be $6-8 \mathrm{~min}$ and cold freshwater was used to activate the sperm.

\section{Optimising the mitotic gynogenesis protocol}

All experiments were done with eggs from the domesticated and commercially available Aquagen strain, Aqua Gen AS, Trondheim, Norway. On 14 December 2011 (Exp2011), $4 \mathrm{ml}$ of milt from one male salmon was diluted with $160 \mathrm{ml}$ milt fluid (1:40). Twelve $15 \mathrm{ml}$ aliquots of the diluted milt were irradiated with UV light for 6 or 8 mins in a $9 \mathrm{~cm}$ petridish at $0.48 \mathrm{mWcm}^{-2}$ and transferred to $25 \mathrm{ml}$ polyethylene (PE) containers and stored refrigerated and in darkness until fertilization. One control group was made with the diluted unirradiated milt. Each of the thirteen sperm aliquots were used to fertilize groups of 1000 salmon eggs which were left to hydrate in $0.5 \mathrm{~L} \mathrm{PE}$ bottles at $8{ }^{\circ} \mathrm{C}$ until pressure treatment. At 3798 (3800), 4000 (4000), 4193 (4200), 4403 (4400), $4605(4600)$ and 4816 (4800) minutedegrees $(\operatorname{minC})$ (minutes"degree Celsius) the PE bottles were transferred to the pressure chamber and the eggs were subjected to a hydrostatic pressure of 655 bar (TRC-APV, Aqua Pressure Vessel, TRC Hydraulics inc., Dieppe, Canada) for 5 mins (the simplified group name is shown in brackets). Also, one batch of eggs fertilized with unirradiated milt were sampled every 10 mins from 540 mins $(4320 \mathrm{minC})$ to determine the first cleavage interval (FCI). The 
samples (10-15 eggs) were cleared in $10 \%$ acetic acid before inspection.

On 12 December 2012 (Exp2012), 6 aliquots of diluted (1:40) sperm were made. Five of these were irradiated $\left(0.45 \mathrm{mWcm}^{-2}\right)$ and stored as described above. The last aliquot was left as an unirradiated control. Five egg groups of $\sim 1500$ (between 1239 and 1788) salmon eggs were fertilized with UV irradiated sperm $(6$ mins) and one group was fertilized with the control sperm. Hydration and pressure treatment was according to Exp2011, but treatments were done at 4713 (4700), 4800 (4800), 4899 (4900), 5011 (5000) and 5123 (5100) $\mathrm{minC}$ in addition to the control fertilization.

\section{Fish management and rearing}

Eggs from Exp2011 were incubated at approximately $6{ }^{\circ} \mathrm{C}$. From 23 April 2012 surviving larvae from the different groups were fed at $12{ }^{\circ} \mathrm{C}$ in individual square grey, covered, fibreglass tanks $(1 \times 1 \times 0.25 \mathrm{~m})$ and the temperature was switched to natural temperature in June 2012. All tanks were fed a commercial salmon feed in excess (Nutra Olympic, Skretting AS, Averøy, Norway) with automatic feeders (ARVO-TEC T Drum 2000, Arvotec, Huutokoski, Finland). Feed was given in small portions through the continuous light photoperiod. For illumination, two $18 \mathrm{~W}$ fluorescent daylight tubes (OSRAM L 18 W/840 LUMILUX, OSRAM $\mathrm{GmbH}$, Ausburg, Germany) were used to produce $960 \mathrm{~lx}$ under water in the centre of the tank. Photoperiod and feeding were controlled automatically by a PC operated system (Normatic AS, Norfjordeid, Norway). On 7 August 2012 the surviving fish were PIT tagged and a small fin-clip was taken for genotyping. After tagging and sampling the experimental fish (including 45 control fish) were transferred to three tanks $(1.5 \times 1.5 \times 0.7 \mathrm{~m})$ for further ongrowing in common garden conditions.

Body mass and fork length were collected at eight time points; Aug 2012, Nov 2012, Jun 2013 (transfer to SW), Nov 2013, Jul 2014, Jun 2015 and Nov 2016. At each sampling time, fish were anaesthetized in $100 \mathrm{mgL}^{-1}$ Finquel $^{\circ}$ (MS 222). In Nov 2012, some stunted individuals were euthanized together with deformed fish (mainly curvatures and shortening of the vertebral column; see reduction in numbers in Additional file 1: Table S1; Fig. 1). Thirty-four control fish were also euthanized. In June 2013, 30 fish from the treatment groups and the remaining 11 controls were radiographed and checked for vertebral deformities. The controls were euthanized during the sampling. When the fish were measured in November 2013 and July 2014 fish were also euthanized (30 fish each time) to get samples for several other studies. Euthanasia was always done in 500 $\mathrm{mgL}^{-1}$ Finquel $^{\circ}$ (MS 222) followed by exsanguination.

Fish were sexed by visual examination of the gonads at the time of terminal sampling. The condition factor (K) was calculated as $\mathrm{K}=100 \mathrm{x}$ weight $(\mathrm{g}) \mathrm{x}$ length $^{-3}(\mathrm{~cm})$. Specific growth rate (SGR, \% per day) was calculated from the formula: $S G R=\left(e^{q}-1\right) \times 100$ [61], where $q=$ $\left[\operatorname{In}\left(\mathrm{W}_{2}\right)-\operatorname{In}\left(\mathrm{W}_{1}\right)\right]\left(\mathrm{t}_{2}-\mathrm{t}_{1}\right)^{-1}[62]$ and where $\mathrm{W}_{2}$ and $\mathrm{W}_{1}$ were the live body weights at times $t_{2}$ and $t_{1}$, respectively. Levels of sexual maturation, based on external morphology, were assessed throughout.

Rearing of the fish produced in Exp2012 was the same as in Exp2011. Surviving larvae were first fed from 22 March. On 18 September 2013 the surviving progeny (240 fish from treatment groups and 30 controls) were tagged with passive integrated transponder (PIT) tags and tissue sampled. From Exp2012 only the survival data and genotyping are presented here.

\section{Production of clonal lines}

In 2014, six females from Exp2011 were sexually mature. On 4 December 2014 they were all ovulated and their eggs were hand stripped and fertilized with three aliquots of diluted and UV irradiated sperm (same protocol as described above with 6 mins irradiation at $454 \mathrm{~mW}$ ). Eggs were left to hydrate in $2 \mathrm{~L} \mathrm{PE}$ bottles at $8{ }^{\circ} \mathrm{C}$ until pressure treatment. At $300 \mathrm{minC}$ (second meiotic division [63]) the PE bottles containing eggs were transferred to the pressure chamber and they were thereafter pressurized for 5 mins at 655 bar. The weight of the females after stripping, the weight of the drained egg mass and the weight of 100 eggs, were recorded.

Rearing conditions for the fish in the clonal lines were the same as for the production of the double haploids described above. Survival to the eyed stage was registered on 10 February 2015 and surviving larvae were counted and first fed from 9 April 2015. On 8 June 2015 (day 60 of feeding), surviving fish were counted, distributed to other experiments and a small number were reared on for sampling and phenotypic description. On 16 November 2015, 8-10 fish from each clonal line were euthanized (500 $\mathrm{mgL}^{-1}$ Finquel $^{\circ}$ (MS 222) and fin tissue samples were taken for microsatellite DNA analysis. On 30 November 2015, the remaining fish were euthanized, a blood sample taken for ploidy determination, length, weight, sex and deformities in the vertebral column were recorded. Deformities recorded included curvatures (lordosis, scoliosis and kyphosis) and/or shortening (short trunk and short tail [64]. Deformities in the head skeleton (upper and lower jaw and opercula) were recorded and as the pelvic fin was found to be missing in some individuals, this was also recorded.

\section{Genotyping}

DNA was extracted from fin-clips. This was performed in 96-well plates using a commercially available extraction kit (Qiagen DNeasy 96 Blood \& Tissue Kit). Each 96-well plate included two blank wells as negative 
controls. The samples were subject to genotyping with a set of 18 microsatellites that are routinely used in the molecular genetics laboratory at the Institute of Marine Research for Atlantic salmon genetics projects including ploidy determination (e.g. [65-67]). The samples taken from Exp2011 and 2012 were analyzed with all 18 of the microsatellites and the clonal fish produced in 2014 were analyzed with 16 of these. These loci were amplified in three multiplexes, using standard protocols for fresh tissues (Additional file 3); SSsp3016 (Genbank no. AY372820), SSsp2210, SSspG7, SSsp2201，SSsp1605, SSsp2216 [68], Ssa197, Ssa171, Ssa202 [69], SsaD157, SsaD486, SsaD144 [70], Ssa289, Ssa14 [71], SsaF43 [72], SsaOsl85 [73], MHC I [74] and MHC II [75]. Polymerase chain reaction (PCR) products were analysed on an $\mathrm{ABI}$ 3730 Genetic Analyser and sized by a $500 \mathrm{LIZ}^{\mathrm{mm}}$ sizestandard. The raw data was checked manually twice.

\section{Statistical analysis}

Data were analysed in GraphPad Prism, version 6.0. Significance was assigned at $p \leq 0.05$. Length, weight, and $K$ factor data were first checked for normality within group using the Shapiro-Wilk test. Subsequently, parametric data were analysed using one-way ANOVA whereas nonparametric data were analysed using the Kruskal-Wallis test with treatment (3-6 levels depending on the timepoint) as a categorical variable. When main effects were significant, we used Tukey's or Dunn's multiple comparisons tests for parametric and non-parametric data, respectively. Each time point was analysed separately.

\section{Supplementary information}

Supplementary information accompanies this paper at https://doi.org/10. 1186/s12863-020-00878-8.

Additional file 1 Table S1. Mean \pm SD (N) weight, length and condition factor $(\mathrm{K})$ and sexual maturation ( $\mathrm{N}$ mature of total $\mathrm{N}$ ) of control fish and fish from the different treatment protocols.

Additional file 2 Table S2. Microsatellite analysis of 2 parents and 362 offspring from Exp2011 (row 1-366). The first 45 individuals (controls) were fertilized with diluted, but unirradiated milt. The others were fertilized with UV-irradiated milt and pressure shocked. Alleles that are exclusive for the Sire (sperm donor) are in green and blue and for the female in red and yellow. Only two individuals from the putative mitotic gynogenetic groups showed any paternal contribution (rows 55 and 216). The females that matured in 2014 and were used to produce the isogenic lines are shown in col. A with the number indicating which line they originated from. Rows 369 to 424 compares the microsatellites of the clonal founders with their progeny. Microsatellite data from Exp2012 is shown in lines 430 to 702 with the parents in lines 430 and 431, the doubled haploid progeny in lines 433 to 672 and the controls in lines 673 to 702.

Additional file 3. Details on condition of PCR reactions

\section{Acknowledgements}

We would like to acknowledge the help of the staff at Matre for production of fish groups.

\section{Authors' contributions}

TJH and DP conceived the study. TJH, PGF and TV performed all the fish studies. AGES performed the laboratory work and quality interpreted it together with KAG. AT developed the UV irradiation protol. TWKF did the statistical analysis and made the figure. TJH wrote the first draft of the manuscript. The author(s) read and approved the final manuscript.

\section{Funding}

This study was financed with resources from the Norwegian Ministry for Trade and Fisheries, the EU Seventh Framework Programme via the AQUAEXCEL project No. 262336 and the European Union's Horizon 2020 research and innovation programme under grant agreement No 652831. The views expressed in this work are the sole responsibility of the authors and do not necessarily reflect the views of any of the above-mentioned funding bodies.

\section{Availability of data and materials}

All relevant data and materials for this study are available from the first author Tom Hansen: tomh@hi.no.

\section{Ethics approval and consent to participate}

All experiments were done at the Institute of Marine Research, Matre Research Station $\left(60^{\circ} \mathrm{N}, 5^{\circ} \mathrm{E}\right.$, Western Norway) which is authorized for animal experimentation (Norwegian Food Safety Authority, facility 110) and in accordance with International guidelines certified using Norwegian research permit number 5281 and 8504

\section{Consent for publication}

All authors read and approved the final manuscript.

\section{Competing interests}

The authors declare that have no competing interests.

\section{Author details}

${ }^{1}$ Institute of Marine Research, 5984 Matredal, Norway. ${ }^{2}$ Institute of Aquaculture, School of Natural Sciences, University of Stirling, Stirling FK9 4LA, Scotland, UK. ${ }^{3}$ Institute of Marine Research, 5817 Bergen, Norway.

${ }^{4}$ Department of Biology, University of Bergen, Bergen, Norway.

Received: 27 April 2020 Accepted: 28 June 2020

Published online: 08 July 2020

\section{References}

1. Ihssen PE, McKay LR, McMillan I, Phillips RB. Ploidy manipulation and gynogenesis in fishes: Cytogenic and fisheries applications. Trans Am Fish Soc. 1990;119:698-717.

2. Streisinger G, Walker C, Dower N, Knauber D, Singer F. Production of clones of homozygous diploid zebra fish (Brachydanio rerio). Nature. 1981;291:293-6.

3. Komen $\mathrm{H}$, Thorgaard $\mathrm{GH}$. Androgenesis, gynogenesis and the production of clones in fishes: a review. Aquaculture. 2007:269:150-73.

4. Sarder MRI, Penman DJ, Myers JM, McAndrew BJ. Production and propagation of fully inbred clonal lines in the Nile tilapia (Oreochromis niloticus L.). J Exp Zool. 1999:284:675-85.

5. Komen J, Bongers ABJ, Richter CJJ, van Muiswinkel WB, Huisman EA. Gynogenesis in common carp (Cyprinus carpio L.) II. The production of homozygous gynogenetic clones and $F_{1}$ hybrids. Aquaculture. 1991;92: $127-42$.

6. Kobayashi T, Ide A, Hiasa T, Fushiki S, Ueno K. Production of cloned amago salmon Onchorhynchus rhodurus. Fish Sci. 1994;60:275-81.

7. Quillet E. Survival growth and reproductive traits of mitotic gynogenetic rainbow trout females. Aquaculture. 1994;123:223-36.

8. Sheerer PD, Thorgaard GH, Allendorf FW. Genetic analysis of androgenetic rainbow trout. J Exp Zool. 1991;260:382-90.

9. Franěk $R$, Baloch AR, Kašpar $V$, Saito T, Fujimoto T, Arai K, Pšenička M. Isogenic lines in fish - a critical review. Rev Aquac. 2019;https://doi.org/ https://doi.org/10.1111/raq.12389.

10. Young WP, Wheeler PA, Coryell VH, Keim P, Thorgaard GH. A detailed linkage map of rainbow trout produced using doubled haploids. Genetics. 1998;148:839-50. 
11. Nichols KM, Young WP, Danzmann RG, Robison BD, Rexroad C, Noakes M, Phillips RB, Bentzen P, Spies I, Knudsen K, Allendorf FW, Cunningham BM, Brunneli J, Zhang H, Ristow S, Drew R, Brown KH, Wheeler PA, Thorgaard $\mathrm{GH}$. A consolidated linkage map for rainbow trout (Oncorhynchus mykiss). Anim Genet. 2003;34:102-15.

12. Nichols KM, Wheeler PA, Thorgaard GH. Quantitative trait analysis loci for meristic traits in Oncorhynchus mykiss. Environ Biol Fish. 2004;69:317-31.

13. Robison BD, Wheeler PA, Sundin K, Sikka P, Thorgaard GH. Composite interval mapping reveals a major locus influencing embryonic development rate in rainbow trout (Oncorhynchus mykiss). J Hered. 2001;92:16-22.

14. Biacchesi S, Le Berre M, Le Guillou S, Benmansour A, Brémont M, Quillet E, Boudinot P. Fish genotype significantly influences susceptibility of juvenile rainbow trout, Oncorhynchus mykiss (Walbaum), to waterborne infection with infectious salmon anaemia virus. J Fish Dis. 2007;30:631-6.

15. Quillet E, Dorson M, Le Guillou S, Benmansour A, Boudinot P. Wide range of susceptibility to rhabdoviruses in homozygous clones of rainbow trout. Fish Shellfish Immunol. 2007;22:510-9.

16. Verrier ER, Dorson M, Mauger S, Torhy C, Ciobotaru C, Hervet C, Dechamp N, Genet C, Boudinot P, Quillet E. Resistance to a rhabdovirus (VHSV) in rainbow trout: identification of a major QTL related to innate mechanisms. PLoS One. 2013:8:e55302.

17. Langevin C, Blanco M, Martin SAM, Jouneau L, Bernardet J-F, Houel A, Lunazzi A, Duchaud E, Michel C, Quillet E, Boudinot P. Transcriptional responses of resistant and susceptible fish clones to the bacterial pathogen Flavobacterium psychrophilum. PLoS One. 2012;7(6):e39126.

18. Dupont-Nivet M, Médale F, Leonard J, Le Guillou S, Tiquet F, Quillet E, Geurden I. Evidence of genotype-diet interactions in the response of rainbow trout (Oncorhynchus mykiss) clones to a diet with or without fishmeal at early growth. Aquaculture. 2009;295:15-21.

19. Geurden I, Borchert P, Balasubramanian MN, Schrama JW, Dupont-Nivet M, Quillet E, Kaushik SJ, Panserat S, Medale F. The positive impact of the earlyfeeding of a plant-based diet on its future acceptance and utilization in rainbow trout. PLoS One. 2013;8:e83162.

20. Teletchea F, Fontaine P. Levels of domestication in fish: implications for the sustainable future of aquaculture. Fish Fish. 2014;15:181-95.

21. Glover KA, Solberg MF, McGinnity P, Hindar K, Verspoor E, Coulson MW Hansen MM, Araki H, Skaala $\varnothing$, Svåsand T. Half a century of genetic interaction between farmed and wild Atlantic salmon: status of knowledge and unanswered questions. Fish Fish. 2017;18:890-927.

22. Lien S, Koop BF, Sandve SR, Miller JR, Kent MP, Nome T, Hvidsten TR, Leong JS, Minkley DR, Zimin A, Grammes F, Grove H, Gjuvsland A, Walenz B, Hermansen RA, von Schalburg K, Rondeau EB, Di Genova A, JKA S, Vik JO, Vigeland MD, Caler L, Grimholt U, Jentoft S, Vage DI, de Jong P, Moen T, Baranski M, Palti Y, Smith DR, Yorke JA, Nederbragt AJ, Tooming-Klunderud A, Jakobsen KS, Jiang XT, Fan DD, Liberles DA, Vidal R, Iturra P, SJM J, Jonassen I, Maass A, Omholt SW, Davidson WS. The Atlantic salmon genome provides insights into rediploidization. Nature. 2016;533:200-5.

23. Grimholt $U$, Johansen $R$, Smith AJ. A review of the need and possible uses for genetically standardized Atlantic salmon (Salmo salar) in research. Lab Anim. 2009;43:121-6.

24. Lincoln RF, Aulstad D, Grammeltvedt A. Attempted triploid induction in Atlantic salmon (Salmo salar) using cold shocks. Aquaculture. 1974;4:287-97.

25. Refstie T. Induction of diploid gynogenesis in Atlantic salmon and rainbow trout using irradiated sperm and heat shock. Can J Zool. 1983;61:2411-6.

26. Quillet $\mathrm{E}$, Gaignon JL. Thermal induction of gynogenesis and triploidy in Atlantic salmon (Salmo salar) and their potential interest for aquaculture. Aquaculture. 1990;89:351-64.

27. Johnstone R, Stet RJM. The production of gynogenetic Atlantic salmon, Salmo salar L. Theor Appl Genet. 1995;90:819-26.

28. Estoup A, Jarne P, Cornuet JM. Homoplasy and mutation model at microsatellite loci and their consequences for population genetics analysis. Mol Ecol. 2002;11:1591-604.

29. Li YC, Korol AB, Fahima T, Beiles A, Nevo E. Microsatellites: genomic distribution, putative functions and mutational mechanisms: a review. Mol Ecol. 2002;11:2453-65.

30. Thorgaard GH, Allendorf FW, Knudsen KL. Gene-centromere mapping in rainbow trout: high interference over long map distances. Genetics. 1983;103:771-83.

31. Battle HI. The embryology of the Atlantic salmon (Salmo salar Linnaeus). Can J Res. 1944;22:105-25.

32. Onozato H. Diploidization of gynogenetically activated salmonid eggs using hydrostatic pressure. Aquaculture. 1984;43:91-7.
33. Sakao S, Fujimoto T, Tanaka M, Yamaha E, Arai K. Aberrant and arrested embryos from masu salmon eggs treated for tetraploidization by inhibition of the first cleavage. Nippon Suisan Gakkaishi. 2003;69:738-48 in Japanese, with English abstract.

34. Sakao S, Fujimoto T, Kimura S, Yamaha E, Arai K. Drastic mortality in tetraploid induction results from the elevation of ploidy in masu salmon Oncorhynchus masou. Aquaculture. 2006;252:147-60.

35. Weber GM, Hostuttler MA. Factors affecting the first cleavage interval and effects of parental generation on tetraploid production in rainbow trout (Oncorhynchus mykiss). Aquaculture. 2012;344-349:231-8.

36. Weber GM, Hostuttler MA, Semmens K, Beers BA. Induction and viability of tetraploids in brook trout (Salvelinus fontinalis) can. J Fish Aquat Sci. 2015;72:1443-9.

37. Hussain MG, Penman DJ, McAndrew BJ, Johnstone R. Suppression of first cleavage in the Nile tilapia Oreochromis niloticus L. - a comparison of the relative effectiveness of pressure and heat shocks. Aquaculture. 1993:11: 263-70.

38. Myers JM, Penman DJ, Basavaraju Y, Powell SF, Baoprasertkul P, Rana KJ, Bromage N, McAndrew BJ. Induction of diploid androgenetic and mitotic gynogenetic Nile tilapia (Oreochromis niloticus L.). Theor. Appl. Genet. 1995;90:205-10.

39. Hersberger WK, Hostuttler MA. Variation in time to first cleavage in rainbow trout Oncorhynchus mykiss embryos: a major factor in induction of Tetraploids. J World Aquacult Soc. 2005;36:96-102.

40. Hersberger WK, Hostuttler MA. Protocols for more effective induction of tetraploid rainbow trout. North Am J Aquacult. 2007;69:367-72.

41. Quillet E, Garcia P, Guyomard R. Analysis of the production of all homozygous lines of rainbow trout by gynogenesis. J Exp Biol. 1991;257: 367-74.

42. Michalik O, Dobosz S, Zalewski T, Sapota M, Ocalewicz K. Induction of gynogenetic and androgenetic haploid and doubled haploid development in the brown trout (Salmo trutta Linnaeus 1758). Reprod Domest Anim. 2015;50:256-62

43. Naruse K, ljiri K, Shima A, Egami N. The production of cloned fish in the Medaka (Oryzias latipes). J Exp Zool. 1985;236:335-41.

44. Arai K. Genetic improvement of aquaculture finfish species by chromosome manipulation techniques in Japan. Aquaculture. 2001;197:205-28.

45. Kato K, Murata O, Yamamoto S, Miyashita S, Kumai H. Viability, growth and external morphology of meiotic- and mitotic-gynogenetic diploids in red sea bream, Pagrus major. J Appl Ichthyol. 2001:17:97-103.

46. Müller-Belecke A, Hörstgen-Schwark G. Sex determination in tilapia (Oreochromis niloticus). Sex ratios in homozygous gynogenetic progeny and their offspring. Aquaculture. 1995;137:57-65.

47. Komen J. Clones of common carp, Cyprinus carpio: new perspectives in fish research. Netherlands: PhD thesis, Department of Fish Culture and Fisheries, Wageningen Agricultural University; 1990. p. 192.

48. Hansen TJ, Fjelldal PG, Yurtseva A, Berg A. A possible relationship between growth and number of deformed vertebrae in Atlantic salmon (Salmo salar L.). J Appl Ichthyol. 2010;26:355-9.

49. Thorpe JE, Miles MS, Keay DS. Developemental rate, fecundity and egg size in Atlantic salmon, Salmo salar L. Aquaculture. 1984:43:289-305.

50. Moffet IJJ, Allen M, Flanagan C, Crozier WW, GJA K. 2006. Fecundity, egg size and early survival for wild Atlantic salmon, from the river bush. Fish Manag Ecol. 2006;13:73-9.

51. Müller-Belecke A, Hörstgen-Schwark G. Performance testing of clonal Oreochromis niloticus lines. Aquaculture. 2000;184:67-76.

52. Hussain MG, Penman DJ, McAndrew BJ. Production of heterozygous and homozygous clones in Nile tilapia. Aquac Int. 1998;6:197-205.

53. Jagiello K, Zalewski T, Dobosz S, Michalik O, Ocalewicz K. 2017. High rate of defomed larvae among gynogenetic brown trout (Salmo trutta m. fario) doubled haploids. Biomed res Int. 2017;2975187.

54. Preston AC, Taylor JF, Craig B, Bozzolla P, Penman DJ, Migaud H. Optimization of triploid induction in brown trout (Salmo trutta L.) Aquaculture. 2013:414-415:160-6.

55. Gillet C, Vauchez C, Haffray P. Triploidy induced by pressure shock in Arctic charr (Salvelinus alpinus): growth, survival and maturation until the third year. Aquat Living Resour. 2001;14:327-34

56. Aegerter $\mathrm{S}$, Jalabert B. Effects of post-ovulatory oocyte ageing and temperature on egg quality and on the occurrence of triploid fry in rainbow trout, Oncorhynchus mykiss. Aquaculture. 2004:231:59-71.

57. Mommens M, Storset A, Babiak I. Some quantitative indicators of postovulatory aging and its effect on larval and juvenile development of Atlantic salmon (Salmo salar). Theriogenology. 2015;84:170-6. 
58. Aulstad D, Kittelsen A. Abnormal body curvatures of rainbow trout (Salmo gairdneri) inbred fry. J Fish Res Bd Can. 1971;28:1918-20.

59. Kinkaid HL. Inbreeding in rainbow trout (Salmo gairdneri). J Fish Res Board Can. 1976:33:2420-6.

60. Otterå $H$, Thorsen A, Peruzzi S, Dahle G, Hansen T, Karlsen $\varnothing$. Induction of gynogenesis in Atlantic cod, Gadus morhua (L.). J Appl Ichthyol. 2011;27: 1298-302.

61. Houde ED, Scheckter RC. Growth rates, rations and cohort consumptions of marine fish larvae in relation to prey concentration. Rapp P-V Reun Cons Int Explor Mer. 1981;178:441-53.

62. Bagenal TB, Tesch FW. Age and growth. Methods for assessment of fish production in fresh waters. In: Bagenal T, editor. IBP Handbook No. 3. 3rd ed. Oxford: Blackwell; 1978. p. 101-36.

63. Benfey TJ, Sutterlin AM. Triploidy induced by heat shock and hydrostatic pressure in landlocked Atlantic salmon (Salmo salar L.). Aquaculture. 1984; 36:359-67.

64. Fjelldal PG, Hansen T, Breck O, Ørnsrud R, Lock E-J, Waagbø R, Wargelius A, Witten PE. Vertebral deformities in farmed Atlantic salmon (Salmo salar L.) etiology and pathology. J Appl Ichthyol. 2012;28:433-40.

65. Glover KA, Quintela M, Wennevik V, Besnier F, Sørvik AGE, Skaala Ø. Three decades of farmed escapees in the wild: a spatio-temporal analysis of population genetic structure throughout Norway. PLoS One. 2012;7:e43129.

66. Glover KA, Madhun AS, Dahle G, Sørvik AGE, Wennevik V, Skaala Ø, Morton $H C$, Hansen TJ, Fjelldal PG. The frequency of spontaneous triploidy in farmed Atlantic salmon produced in Norway during the period 2007-2014. BMC Genet. 2015:16:37.

67. Wennevik V, Quintela M, Skaala $\varnothing$, Verspoor E, Prusov S, Glover KA. Population genetic analysis reveals a geographically limited transition zone between two genetically distinct Atlantic salmon lineages in Norway. Ecol Evol. 2019;9:6901-21.

68. Paterson S, Piertney SB, Knox D, Gilbey J, Verspoor E. Characterization and PCR multiplexing of novel highly variable tetranucleotide Atlantic salmon (Salmo salar L.) microsatellites. Mol Ecol Notes. 2004;4:160-2.

69. O'Reilly PT, Hamilton LC, SK MC, Wright JM. Rapid analysis of genetic variation in Atlantic salmon (Salmo salar) by PCR multiplexing of dinucleotide and tetranucleotide microsatellites. Can J Fish Aquat Sci. 1996; 53:2292-8.

70. King TL, Eackles MS, Letcher BH. Microsatellite DNA markers for the study of Atlantic salmon (Salmo salar) kinship, population structure, and mixedfishery analyses. Mol Ecol Notes. 2005;5:130-2.

71. McConnell SK, Oreilly P, Hamilton L, Wright JN, Bentzen P. Polymorphic microsatellite loci from Atlantic salmon (Salmo salar) - genetic differentiation of north-American and European populations. Can J Fish Aquat Sci. 1995;52:1863-72

72. Sanchez JA, Clabby C, Ramos D, Blanco G, Flavin F, Vazquez E. Powell R, Protein and microsatellite single locus variability in Salmo salar $\mathrm{L}$ (Atlantic salmon). Heredity. 1996;77:423-432.

73. Slettan A, Olsaker I, Lie O. Atlantic salmon, Salmo salar, microsatellites at the SSOSL25, SsOSL85, SsOSL311, SsOSL417 loci. Anim Genet. 1995;26:281-2.

74. Grimholt U, Drablos F, Jørgensen SM, Høyheim B, Stet RJM. The major histocompatibility class I locus in Atlantic salmon (Salmo salar L.): polymorphism, linkage analysis and protein modelling. Immunogenetics. 2002;54:570-81.

75. Stet RJM, de Vries B, Mudde K, Hermsen T, van Heerwaarden J, Shum BP, Grimholt U. Unique haplotypes of co-segregating major histocompatibility class II a and class II B alleles in Atlantic salmon (Salmo salar) give rise to diverse class II genotypes. Immunogenetics. 2002;54:320-31.

\section{Publisher's Note}

Springer Nature remains neutral with regard to jurisdictional claims in published maps and institutional affiliations.

Ready to submit your research? Choose BMC and benefit from:

- fast, convenient online submission

- thorough peer review by experienced researchers in your field

- rapid publication on acceptance

- support for research data, including large and complex data types

- gold Open Access which fosters wider collaboration and increased citations

- maximum visibility for your research: over $100 \mathrm{M}$ website views per year

At BMC, research is always in progress.

Learn more biomedcentral.com/submissions 